\title{
Book Review: Gloria Naylor's Fiction: Contemporary Explorations of Class and Capitalism by Ama S. Wattley and Sharon A. Lewis
}

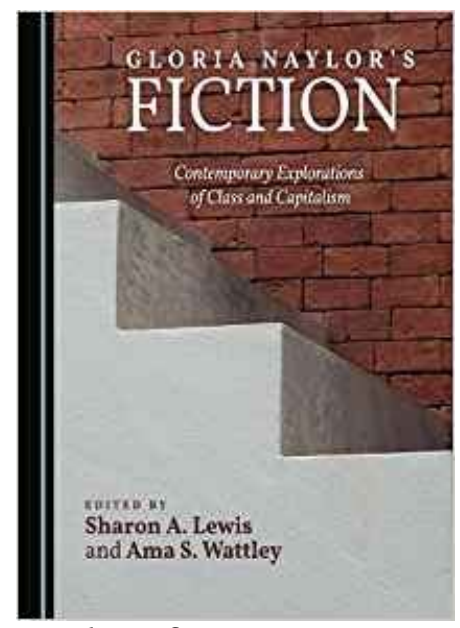

Number of Pages: 132

Publication Year: 2017

Publisher: Cambridge Scholars Publishing

ISBN (10): 1-4438-9591-1

ISBN (13): 978-1-4438-9591-0

Price: \$ 99.95

Reviewed by

Adishree Vats

School of Languages and Literature, Shri Mata Vaishno Devi University, atsadishree8@gmail.com

The book Gloria Naylor's Fiction: Contemporary Explorations of Class and Capitalism, by Ama S. Wattley and Sharon A. Lewis, displays a compendium of analytical essays by different critics, who very meticulously illustrate, by applying Marxism and Black feminism, how Gloria Naylor makes her readers to ponder over African Americans' equation with "social class, economics, and capitalism" (p. 1), and uncovers various approaches leading to the deconstruction of "oppositional class model" (p. 13). This revelatory critical collection focuses on Naylor's five works in the order of their publication: The Women of Brewster Place (Naylor, 1983), Linden Hills (Naylor, 1985), Mama Day (Naylor, 1988), Bailey's Cafe (Naylor, 1992), and The Men of Brewster Place (Naylor, 1998). A chapter is devoted to each of these novels, in order to lay bare the totality of the AfroAmerican human predicament vis-a-vis the Black American female for whom the hegemonistic appropriations of Whites, and problematics of social classes continue to exist.

The Introduction by the editors, Lewis and Wattley, becomes a revelatory exegesis upon Naylor's realization that social class is "convoluted and complicated" (p. 3), and politics of class and capitalism poses a "deepest, largest challenge" (hooks, 2000). Naylor's novels present a vivid and

(C) AesthetixMS 2018. This Open Access article is published under a Creative Commons Attribution Non-Commercial 4.0 International License (http://creativecommons.org/licenses/by-nc/4.0/), which permits non-commercial re-use, distribution, and reproduction in any medium, provided the original work is properly cited. For citation use the DOI. For commercial re-use, please contact editor@rupkatha.com. 
spectacular explanation about "what it means for Black Americans to inhabit a capitalist nation" (p. 3) and by proposing such arguments, she explores the existence of middle class and upper middle class Blacks in the US. With a concentrated and thematic essence, they extend their explanation by asserting that other African American writers have as well manifested the same concerns, but Naylor "foregrounds the motif of economics, class and capitalism in a more complex, intricate way" (p. 2).

In chapter one, "I Need a Prince To Watch Over Me. Really?! Re-visioning 'Happily Ever After' in Gloria Naylor's The Women of Brewster Place" (p. 23), August demonstrates the re-drafting of fairy tales how they incorporate within themselves key factors like "submission" (Painter, 1993, p. 9), "obedience" (Painter, 1993, p. 9) and "piety" (Painter, 1993, p. 24), which not only indicate the peculiarities of a decent womanhood, but also that of American slavery. Furthermore, Naylor vehemently gives a nod to the fairytale-cliche "happily ever after" (p. 29) and optimistically declares that happiness does not stand for getting married to your dream man, rather it involves symbolically transforming and breaking down "the Wall" (p. 41), that represents "patriarchal and economic injustice" (p. 41) which makes black women's lives "enclosed, isolated, and alienated" (p. 29) .

In the second chapter, "Keep Your Check: Commodity, Capitalism and Commerce in Gloria Naylor's Mama Day", Mitchell talks about how Naylor's Mama Day throws light upon the "patterns of gentrification and economic upheaval" (p. 45) among the upper middle-class Blacks in the US. Black neighborhoods in big American cities, like New York, are "transforming into locales for elite" (p. 45). Mitchell further explains how European countries commercialize and exploit African nations for their resources, and even their people, for their own benefits. Here, she gives the reference of "Gullah-Geechee islands" (p. 45) which have been subjected to "massive land-grabbing and upheaval" (p. 45), and lays outright emphasis on the fact that "Black economic wealth, land possession, autonomy and community are priceless" (p. 58). Similarly, in Mama Day, people display their honor and pride by not selling Willow Springs to the capitalists, as they believed that "to sell the land is, in essence, to sell their selves" (p. 47).

In chapter three, "Gloria Naylor's Bailey's Cafe: Selling Sex in the Cultural Marketplace", Montgomery asserts that the novel, through its narrative matrix, makes an attempt to formulate a space for women to define their sexuality for their own liberation and "eradicate the dynamics involved in a for-profit, money-exchange system" (p. 63). Naylor, in the novel, very painstakingly tears into pieces the "Virgin Whore dichotomy" (p. 63) as, according to her, Black women get encapsulated within the historical prototypes and stereotypical roles within the structures of bourgeois capitalism. She further makes an effort to deconstruct the historical epigraphs of identity and "re-inscribe the sexually-transgressive figure" (p. 66).

In chapter four, "In the Shadow of Cosby: Gloria Naylor's Linden Hills and the Postintegration Black Elite", Tucker highlights that the novel depicts how the "Afristocracy[ts]" (p. 78) endeavor to splinter their ties with their black working and underclass brethrens in lieu of status and material gains, and follows the ideals of "the mainland" (Fowler, 1996, p. 92). The novel, according to Fowler, "suggests a correlation between moral bankruptcy and material success" (Fowler, 1996, p. 61). Tucker, then, suggests that this black working and underprivileged class can be made aware of its exploitation by political, economic and racial forces that impede its gross escalation only by the provision of education.

In chapter five, "The Price of Identity in Linden Hills", Willis argues that the essence of the novel Linden Hills lies within Naylor's art of framing names. In the Black world, no-name clearly depicts the non-existence of the entity. The Blacks, in their pursuit of wealth and fame, have put their 
"self" (p. 102) at stake. With the allurement of consumerism, these Blacks have lost their names and identities. The novel brilliantly dwells into this notion when the word "de-Eden" (p. 103) is translated by Naylor herself into "Nedeed" (p. 103), giving a slanting reference of the "First Garden" (p. 103) with "obvious converse connotations" (p. 103). Smyth (previously Smith) willingly gives up his most prized possession, his racial identity, by changing spellings of his name. And, the Nedeed wives, who are simply referred to as "Mrs. Nedeed" (p. 108), possess no individual recognition. Most of the characters have lost "the power of their names" (p. 113), as they are ensnared in the trap of "capitalistic success" (p. 113).

In chapter six, "The Economics of Identity in The Men of Brewster Place", Wilson, Jr. portrays that the novel becomes a veiled satire on the imperfections and shortcomings of the principal characters. He says, "In a capitalist society, men are identified by how well they succeed economically, how well they take care of their families" (p. 115). Black masculinity, in the context of the US, compulsorily has to come in terms with "the legacy of enslavement" (Lewis, 20o8, p. 48). The lives of these men are burdened with "chronic disappointment" (p. 115). The notion, that Black men are lazy and unreliable, is vehemently opposed by Ben, the janitor of Brewster Place, who argues that these men do their utmost in most hostile situations for the survival of their families and communities. They "decolonize their minds [and] refuse to see themselves as inferior [and deny] to accept dependence and/or defeat as normal" (Pastourmatzi, 2008, p. 300).

From the readers' or scholars' perspective, this collage of critical essays on the fiction of Gloria Naylor, is a must to enhance scholarship besides serving as an important secondary source to be employed in the writing of any doctoral thesis on the African American quintessence of Naylor's novels from the Black feminist perspective. This work of critical essays, reflects in totality the perverted ethos of Mass Society in which Black femininity becomes a veritable scapegoat at the hands of patriarchal tyranny and economic and sexual exploitation. It is not only Black versus White, but Black versus Black as well. The politics of capitalism and class becomes the ultimate challenge.

\section{References}

Fowler, V. C. (2000). Gloria Naylor: In Search of Sanctuary. New York: Twayne.

Hooks, b. (2000).Where We Stand: Class Matters. New York: Routledge.

Lewis, L. (2008). Constructing Black Masculinity Through the Fiction of Gloria Naylor. In L. Lewis, G. Griffith, et al. (Eds.), Color, Hair, and Bone: race in the Twenty-First Century (pp. 47-68). Lewisburg: Bucknell UP.

Lewis, S. A., \& Wattley, A. S. (Eds.). (2017). Gloria Naylor's Fiction: Contemporary Explorations of Class and Capitalism. UK: Cambridge Scholars Publishing.

Naylor, G. (1992). Bailey's Cafe. New York: Vintage.

Naylor, G. (1985). Linden Hills. New York: Penguin.

Naylor, G. (1988). Mama Day. New York: Vintage.

Naylor, G. (1998). The Men of Brewster Place. New York: Hyperion.

Naylor, G. (1983). The Women of Brewster Place. New York: Penguin. 
Pastourmatzi, D. (2008). Insufferable Pain and Psychic Torment: The Anguish of Being a Black Man in Gloria Naylor's the Men of Brewster Place. In C. Lascaratou, A. Despotopoulou, et al. (Eds.), Reconstructing Pain and Joy: Linguistic, Literary and Cultural Perspectives (pp. 300). Cambridge, UK: Cambridge Scholars Publishing.

Painter, N. I. (1993). Soul Murder and Slavery. The Fifteenth Charles Edmonson Historical Lectures (pp. 9). Waco, Texas: Baylor University Press. 